\title{
Performance of Self Compacting High Strength Fiber Reinforced Concrete (SCHSFRC)
}

\author{
Vinayak B. Jatale ${ }^{1}$, M. N. Mangulkar ${ }^{2}$ \\ ${ }^{I}(P G$ Student, Department of Civil Engineering, MGM's Jawaharlal Nehru Engineering College, \\ Aurangabad/Dr. B.A. Marathwada University, Aurangabad, India) \\ ${ }^{2}$ (Assistant Professor, Department of Civil Engineering, MGM's Jawaharlal Nehru Engineering College, \\ Aurangabad/Dr. B.A. Marathwada University, Aurangabad, India)
}

\begin{abstract}
In this experimental study the changes on some mechanical properties of self compacting concrete specimen produced by silica fume, metakaolin, fly ash and steel fibers were investigated. The main objective of this is to obtain ductile Self Compacting High Strength Concrete (SCHSC) which flows under its own weight and homogeneity while completely filling any formwork and passing around congested reinforcement. The Self Compacting High Strength Concrete produced by using silica fume, metakaolin, fly ash, steel fibers and Polycarboxylatether base superplasticizer. Three types of steel fibers were used in the experiments and volume fractions of steel fiber were $0.5 \%$ to $4.0 \%$. Addition of silica fume, metakaolin and fly ash into the concrete were $2.5 \%, 2.5 \%$ and $10 \%$ by weight of cement content respectively. Water/cement ratio was 0.29. Compressive strength and split tensile strength tests were made on hardened concrete specimens.

Keywords-Compressive Strength, Fly Ash, High Strength Concrete (HSC), High Strength Fiber Reinforced Concrete (HSFRC), Metakaolin, Silica fume, Split Tensile Strength, Steel Fibres.
\end{abstract}

\section{Introduction}

Construction of durable concrete structures requires skilled labor for placing and compacting concrete. Self Compacting Concrete achieves this by its unique fresh state properties. In the plastic state, it flows under its own weight and homogeneity while completely filling any formwork and passing around congested reinforcement. In the hardened state, it equals or excels standard concrete with respect to strength and durability.

This work is aimed to study the performance of steel fiber reinforced self compacting concrete as plain self compacting concrete is studied in depth but the fiber reinforced self compacting concrete is not studied to that extent. The main objective of this study is to optimize the Steel Fiber Reinforced Self Compacting High Strength Concrete (SFRSCHSC) in the hardened state. But the literature indicates that some studies are available on plain SCC but sufficient literature is not available on Steel Fiber Reinforced Self Compacting High Strength Concrete (SFRSCHSC) with different mineral admixtures. Hence an attempt is made in this work to study the mechanical properties of both plain Self Compacting High Strength Concrete (SCHSC) and SFRSCC.

\section{$2.1 \quad$ Cement}

\section{Material Used}

Ordinary Portland Cement of 53 Grade conforming to IS: 12269-1987 was used in the investigation. The specific gravity of cement was 3.10 .

\subsection{Coarse Aggregate}

Crushed stone metal with a maximum size of $12.5 \mathrm{~mm}$ from a local source having the specific gravity of 2.7 conforming to IS: $383-1970$ was used.

\subsection{Fine Aggregate}

Locally available river sand passing through $4.75 \mathrm{~mm}$ IS sieve conforming to grading zone-II of IS: 383-1970 was used. The specific gravity of fine aggregate was 2.54 .

\subsection{Silica fume}

The American Concrete Institute (ACI) defines silica fume as "very fine noncrystalline silica produced in electric arc furnace as a byproduct of production of elemental silicon or alloys containing silicon". Silica fume is also known as micro silica, condensed silica fume, volatized silica or silica dust. The physical properties and chemical composition of Silica fume are shown in table 2.1 and table 2.2 respectively.

Metakaolin is not a byproduct. It is obtained by the calcinations of pure or refined Kaolinite clay at a 
temperature between $650^{\circ} \mathrm{C}$ and $850^{\circ} \mathrm{C}$, followed by grinding to achieve a fineness of $700-900 \mathrm{~m}^{2} / \mathrm{kg}$. Metakaolin is a high quality pozzolonic material, which is blended with cement in order to improve the durability of concrete. The physical properties and chemical composition of metakaolin are shown in table 2.1 and table 2.2 respectively.

Table 2.1: Physical Properties of Silica Fume \& Metakaolin

\begin{tabular}{|c|c|c|c|c|}
\hline Property & Specific Gravity & Bulk Density $\left(\mathrm{g} / \mathrm{cm}^{3}\right)$ & Physical Form & Colour \\
\hline Silica Fume & 2.27 & 0.13 to 0.43 & Powder & White \\
\hline Metakaolin & 2.60 & 0.3 to 0.4 & Powder & Off White \\
\hline
\end{tabular}

Table 2.2: Chemical Composition of Silica Fume \& Metakaolin

\begin{tabular}{|c|c|c|c|c|c|c|c|c|c|c|}
\hline \multicolumn{2}{|l|}{ Oxide } & $\mathrm{SiO}_{2}$ & $\mathrm{AL}_{2} \mathrm{O}_{3}$ & $\mathrm{Fe}_{2} \mathrm{O}_{3}$ & $\mathrm{CaO}$ & $\mathrm{MgO}$ & $\mathrm{K}_{2} \mathrm{O}$ & $\mathrm{SO}_{3}$ & $\mathrm{Na}_{2} \mathrm{O}$ & L.O.I. \\
\hline$\%$ by & SF & 92.1 & 0.5 & 1.4 & 0.5 & 0.3 & 0.7 & 0.0 & 0.3 & 2.8 \\
\hline mass & $\begin{array}{l}\mathbf{M} \\
\mathbf{K}\end{array}$ & 51.52 & 40.18 & 1.23 & 2.0 & 0.12 & 0.53 & 0.0 & 0.08 & 2.01 \\
\hline
\end{tabular}

\subsection{Fly Ash}

Fly ash is available in dry powder form and is procured from Dirk India Pvt. Ltd., Nasik. The light grey fly ash under the product name "Pozzocrete 83 " is available in $30 \mathrm{~kg}$ bags. The fly ash produced by the company satisfies all the requirements of the IS: 3812-1981.

\subsection{Super plasticizer}

Polycarboxylatether base Muraplast FK 30 super plasticizer obtained from MC-Bauchemie (India) Pvt. Ltd. was used. It conforms to IS: 9103-1999.

\subsection{Steel Fibres}

The main variables used in the study are three different types of steel fibress, i.e. Waved Steel Fibres (WSF), Hook Ended Steel Fibres (HESF) and Flat Steel Fibres (FSF) with different dosages of fibress are used by weight of cementations material.

Table 2.3: Properties of Steel Fibres used

\begin{tabular}{|c|c|c|c|}
\hline Type & Length L (mm) & Diameter d (mm) & Aspect Ratio (L/d) \\
\hline WSF & 25 & 0.55 & 45 \\
\hline FSF & 30 & 2 mm thick & 15 \\
\hline HESF & 25 & 0.55 & 45 \\
\hline
\end{tabular}

\subsection{Water}

Fresh portable water which is free from concentration of acid and organic substances is used for mixing the concrete and curing.

\section{Mixture Proportion And Specimen Preparation}

The experimental investigation was carried out to study the properties of high strength concrete of M70 grade which was design by DoE method. Silica fume was added as $2.5 \%$ weight of cementitious material and fly is by $10 \%$ weight of cementitious material. There are three types of steel fibress are used in this investigation, i.e. Waved Steel Fibres (WSF), Hook Ended Steel Fibres (HESF) and Flat Steel Fibres (FSF) with different dosages of fibress are used by $0.5 \%, 1 \%, 1.5 \%, 2 \%, 2.5 \%, 3 \%, 3.5 \%$ and $4 \%$ weight of cementations material. Table 3.1 shows the mixtures used and their compositional contents. 
Table 3.1: Mix Proportion

\begin{tabular}{|c|l|c|}
\hline Sr. No & Material & Mass \\
\hline 1 & Cementitious Material & $556 \mathrm{Kg} / \mathrm{m}^{3}$ \\
\hline 2 & Ordinary Portland Cement $(85 \%$ of & \\
& CM) & $472.6 \mathrm{Kg} / \mathrm{m}^{3}$ \\
\hline 3 & Silica fume $(2.5 \%$ of CM) & $13.75 \mathrm{Kg} / \mathrm{m}^{3}$ \\
\hline 4 & Metakaolin $(2.5 \%)$ & $13.75 \mathrm{Kg} / \mathrm{m}^{3}$ \\
\hline 5 & Fly Ash $(10 \%$ of CM) & $55.6 \mathrm{Kg} / \mathrm{m}^{3}$ \\
\hline 6 & Fine Aggregate & $702 \mathrm{Kg} / \mathrm{m}^{3}$ \\
\hline 7 & Coarse Aggregate & $1042 \mathrm{Kg} / \mathrm{m}^{3}$ \\
\hline 8 & Water & $162 \mathrm{Kg} / \mathrm{m}^{3}$ \\
\hline \multirow{2}{*}{9} & Superplasticizer & $18 \mathrm{ml} \mathrm{per} \mathrm{kg} \mathrm{of}$ \\
& & $\mathrm{Cement}$ \\
\hline 10 & Water Binder Ratio & 0.29 \\
\hline
\end{tabular}

\subsection{Compressive Strength}

\section{Methodology}

For compressive strength test, cube specimens of dimensions (100 mm x $100 \mathrm{~mm}$ x $100 \mathrm{~mm})$ were cast. The specimens were demoulded after 24 hours of casting and were transferred to curing tank for 28 days. The compressive strength of concrete was determined in accordance with Indian Standards IS: 516-1959. The result obtained are shown in Table 4.1

Table 4.1: Compressive Strength at 28 Days

\begin{tabular}{|c|c|c|c|c|}
\hline \multirow{2}{*}{ Sr. No } & \multirow{2}{*}{$\begin{array}{c}\text { Fibres Volume Fraction } \\
\qquad \mathrm{V} f(\%)\end{array}$} & \multicolumn{3}{|c|}{ Compressive Strength At 28 Days (MPa) } \\
\hline & & WSF & FSF & HESF \\
\hline 1 & 0 & 73.30 & 73.30 & 73.30 \\
\hline 2 & 0.5 & 77.85 & 74.40 & 74.50 \\
\hline 3 & 1.0 & 81.25 & 77.80 & 75.85 \\
\hline 4 & 1.5 & 83.40 & 79.25 & 77.38 \\
\hline 5 & 2.0 & 84.50 & 80.75 & 77.85 \\
\hline 6 & 2.5 & 85.30 & 81.40 & 78.85 \\
\hline 7 & 3.0 & 86.50 & 83.50 & 79.60 \\
\hline 8 & 3.5 & 87.40 & 84.85 & 81.55 \\
\hline 9 & 4.0 & 85.65 & 82.80 & 80.15 \\
\hline
\end{tabular}

\subsection{Split Tensile Strength}

For split tensile strength test, cylinder specimens of dimensions (150 mm x $300 \mathrm{~mm})$ were cast. The specimens were demoulded after 24 hours of casting and were transferred to curing tank for 28 days. These specimens were tested under Universal Testing Machine. The result obtained are shown in Table 4.2 
Table 4.2: Split Tensile Strength at 28 Days

\begin{tabular}{|c|c|c|c|c|}
\hline \multirow{2}{*}{ Sr. No } & \multirow{2}{*}{$\begin{array}{c}\text { Fibres Volume Fraction } \\
\qquad \mathrm{V} f(\%)\end{array}$} & \multicolumn{3}{|c|}{ Compressive Strength At 28 Days (MPa) } \\
\hline & & WSF & FSF & HESF \\
\hline 1 & 0 & 3.67 & 3.67 & 3.67 \\
\hline 2 & 0.5 & 3.89 & 3.72 & 3.73 \\
\hline 3 & 1.0 & 4.06 & 3.89 & 3.79 \\
\hline 4 & 1.5 & 4.17 & 3.96 & 3.87 \\
\hline 5 & 2.0 & 4.23 & 4.04 & 3.89 \\
\hline 6 & 2.5 & 4.27 & 4.07 & 3.94 \\
\hline 7 & 3.0 & 4.33 & 4.18 & 3.98 \\
\hline 8 & 3.5 & 4.37 & 4.24 & 4.08 \\
\hline 9 & 4.0 & 4.28 & 4.14 & 4.01 \\
\hline
\end{tabular}

\subsection{Effect of fibres content (\%) on Compressive Strength of High Strength Concrete}

The compressive strength increases significantly due to the addition of steel fibres compared with normal concrete. In general, the compressive strength of the concrete having Round Crimped Steel Fibres (WSF) was higher than that of concrete with Flat Crimped Steel Fibres (FSF) and Hook Ended Steel Fibres (HESF) at the same volume fractions of steel up to the limit. The compressive strength of concrete with steel fibres is increased up to the $3 \%$ of fibres volume fraction and then decreases. The maximum values of compressive strength at $3 \%$ fibres volume fraction are $89.40 \mathrm{~N} / \mathrm{mm}^{2}, 86.85 \mathrm{~N} / \mathrm{mm}^{2}$ and $83.55 \mathrm{~N} / \mathrm{mm}^{2}$ for WSF, FSF and HESF respectively. The effect of Silica fume, fly ash and steel fibres on compressive strength of concrete shown in figure 5.1.

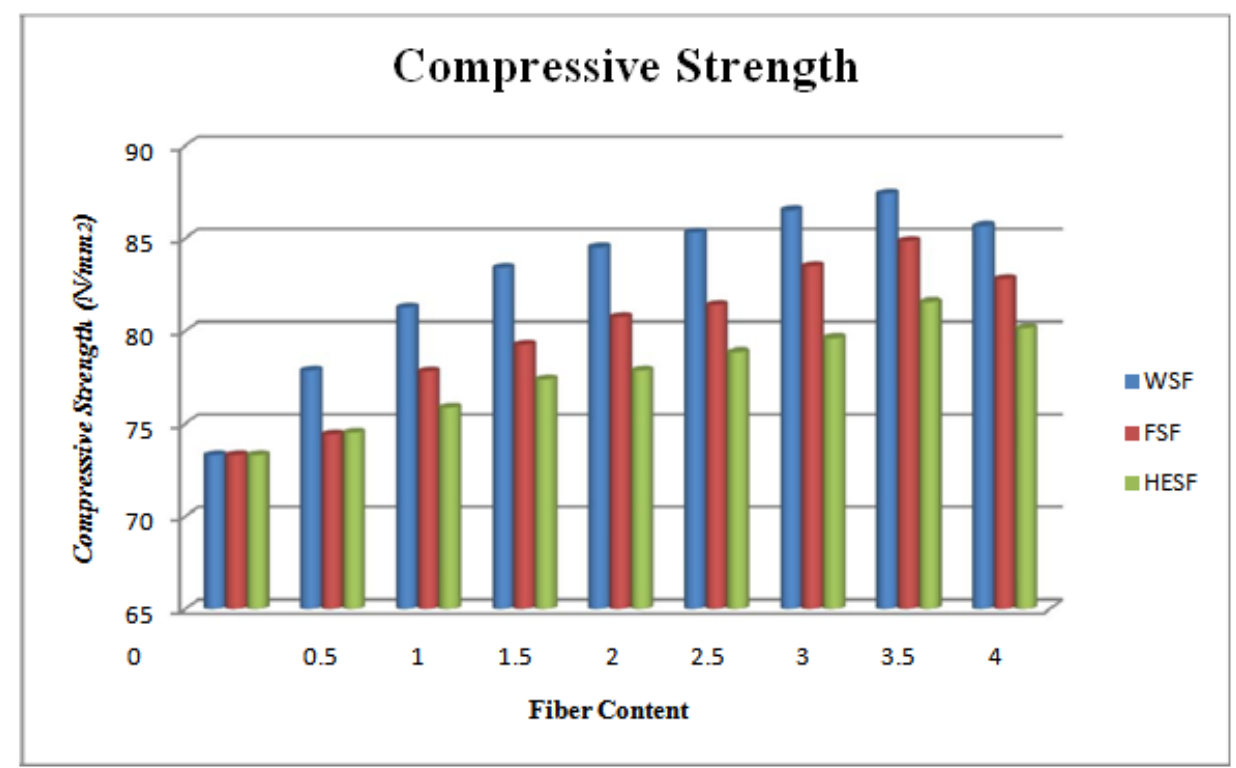

Fig. 5.1 Compressive Strength of concrete with percentage variation of Steel Fibress 


\subsection{Effect of fibres content (\%) on Split Tensile Strength of High Strength Concrete}

The result from Table 4.2 shows that the cylinder split tensile strength of concrete increases considerably with an increase in fibres content. A continuous increase in strength is observed up to a limit. The $3.5 \%$ of fibres content has given maximum increase in split tensile strength as compared to that of normal concrete. The Flat Crimped Steel Fibres (FSF) gives maximum split tensile strength than that of Round Crimped Steel Fibres (WSF) and Hook Ended Steel Fibres (HESF). The effect of Silica fume, Metakaolin, fly ash and steel fibres on split tensile strength of concrete shown in figure 5.2.

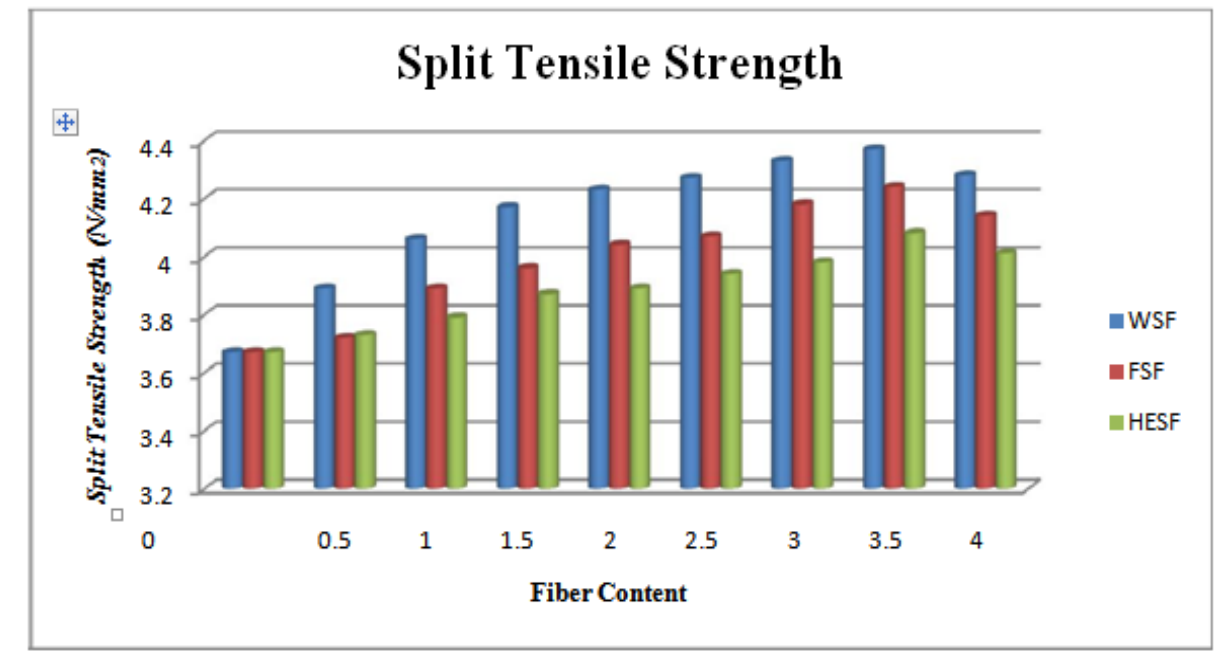

Fig. 5.2 Split Tensile Strength of concrete with percentage variation of Steel Fibress

\section{Conclusion}

Following conclusions are drawn based on the result discussed above:

1. In general, the significant improvement in various strengths is observed with the inclusion of steel fibres in the plain concrete.

2. In general the compressive strength and the flexural strength increase with increase in the percentage of fiber content up to certain limit.

3. The optimum fiber content for increase in compressive and split tensile strength is $3.5 \%$.

4. The compressive strength and split tensile strength of concrete increasing with fibres content. The maximum value of compressive strength gives the WSF and split tensile strength gives FSF at $3.5 \%$ fibres content.

\section{References}

[1] Hajime Okamura and Masahiro Ouchi, "Self Compacting Concrete", Journal of Advanced Concrete Technology Vol. 1, No. 1, April 2003, pp. 5-15

[2] Khayat K. H., "Workability, Testing and Performance of Self Consolidating Concrete", ACI Materials Journal, Vol. 96 , No. 3 , May-June 1999, pp.346-354.

[3] EFNARC, "The European Guidelines for Self Compacting Concrete Specification, Production and Use", May 2005.

[4] Jacek K.," Steel Fiber and Steel Fiber Reinforced Concrete in Civil Engineering”, The Pacific Journal of Scie nce And Technology, Vol. 7, No. 1, May2006, pp.53-58

[5] Chuan Mein Wong, "Use of Short Fibres in Structural Concrete to Enhance Mechanical Properties", University of Southern Queensland, November 2004.

[6] Rame G. M., Narasimhan M.C., Karisddappa and Rajeeva S. V., "Study of the Properties of SCC with Quarry Dust", The Indian Concrete Journal published by ACC limited, Vol.83, No.8, August 2009, pp.54-60.

[7] Joaquim A.O.B., Lucio A.P., Varma R.K. and Delfina M.F., "Cost Competitive Steel Fiber Reinforced SCC for Structural Applications", The Indian Concrete Journal published by ACC limited, Vol.83, No.8, August 2009, pp.15 -26.

[8] IS: 456-2000, "Indian Standard for code of practice for plain and reinforced concrete".

[9] IS: 383-1970. "Specification for course and Fine Aggregates from natural sources for concrete." Bureau of Indian standards, New Delhi.

[10] IS: 516-1959, Edition 1.2 (1991-07), "Indian Standard for Methods of test for strength of concrete.

[11] Sadr Momtazi A, Ranjbar M. M., Balalaei F, Nemati R, "The effect of Iran's Silica fume in enhancing the concrete compressive strength", Cement and Concrete Research,pp.-1-7. 